\title{
ANALISIS KOMPETENSI PEDAGOGIK GURU IPS DALAM PENGEMBANGAN KETERAMPILAN SOSIAL ANAK BERKEBUTUHAN KHUSUS (STUDI KASUS SMP N 12 SEMARANG)
}

\author{
Azizah Nur Aini Muslichah, Aisyah Nur Sayidatun Nisa
}

Social Science Education Department, Faculty of Social Science, Universitas Negeri Semarang, Indonesia

\section{Info Artikel}

Sejarah Artikel:

Disubmit: Juni

Direvisi: Juni

Diterima: Juni

\section{Keywords:}

Pedagogical Competence, Social Skills Development

\begin{abstract}
Abstrak
Guru mempunyai peran penting dalam pelaksanaan pembelajaran terutama penguasaan terhadap karakteristik setiap peserta didik. Oleh karena itu guru harus dapat menguasai kompetensi pedagogik untuk mengembangkan keterampilan sosial terutama pada peserta didik berkebutuhan khusus di sekolah inklusi. Metode penelitian yang digunakan adalah metode kualitatif. Hasil penelitian menunjukkan bahwa (1) Guru IPS telah mengimplementasikan ilmu pedagogik dengan baik sehingga dapat mengembangkan keterampilan sosial dari peserta didik berkebutuhan khusus (2) Faktor pendorong pengembangan keterampilan sosial anak berkebutuhan khusus yaitu dengan ketersediaan guru pendamping khusus, kerjasama sekolah dengan orangtua serta sarana dan prasarana (3) Sedangkan, faktor penghambat pengembangan keterampilan sosial berasal dari rasa kepercayaan diri yang rendah dari peserta didik berkebutuhan khusus sendiri dan kurangnya pelatihan pembelajaran kelas inklusi untuk guru mata pelajaran.
\end{abstract}

\section{Abstract}

The teacher has an important role in the implementation of learning. Especially in masterring the characteristics of each students. Therefore teachers must be able to master pedagogical competencies to develop social skills especially in students with special needs in inclusive schools. The reseach method used is a qualitative method. The results showed that (1) Social studies teachers have implemented pedagogic science well so that they can develop social skills of students with special needs (2) Supporting factors for the development of social sskills of children with special needs is the availability of shadow teacher, school collaboration with parents, and facilities and infrastucture (3) Meanwhile, the inhibiting factor for the development of social skills stem from love self-confidence of students with special needs themselves.

(C) 2020 Universitas Negeri Semarang

\footnotetext{
Alamat korespondensi:

ISSN 2548-4641

Gedung C1 Lantai 1 FIS Unnes

Kampus Sekaran, Gunungpati, Semarang, 50229

E-ISSN 2548-4648

E-mail: azizahmuslichah@gmail.com, aisyah8816@mail.unnes.ac.id
} 


\section{PENDAHULUAN}

Pendidikan merupakan hak untuk setiap masyarakat. Setiap manusia tidak terlepas dari hak kebijakan untuk memperoleh pendidikan baik secara formal maupun informal. Bahkan dalam lingkungan terkecil yaitu dalam sebuah keluarga, seorang anak berhak untuk mendapatkan pendidikan dari kedua orangtuanya. Tidak terkecuali terhadap kehadiran Anak Berkebutuhan Khusus (ABK), dimana mereka mempunyai hak yang sama untuk memperoleh kesetaraan terutama dalam bidang pendidikan.

Pemerintah memberikan fasilitas khusus untuk anak berkebutuhan khusus dalam memperoleh pendidikan secara formal. Pemerintah juga memberikan fasilitas kepada anak berkebutuhan khusus dapat menempuh pendidikan pada sekolah regular / terpadu. Sekolah terpadu merupakan sekolah regular yang menerima anak berkebutuhan khusus, dengan kurikulum dan sarana prasarana yang sama untuk seluruh peserta didik. Sekolah

Menurut Stainback dan Sianback (1990) yang dikutip dalam kemendikbud (2016) mengungkapkan bahwa penyelenggara sekolah inklusif harus menyediakan program pendidikan yang layak, dimana disesuaikan dengan kebutuhan dan kemampuan peserta didik dengan bantuan serta dukungan yang diberikan oleh para guru agar peserta didik tersebut dapat berhasil. Salah satu aspek penting yang harus dimiliki oleh seorang guru untuk memberikan bentuk pengajaran yang baik adalah menguasai kompetensi guru salah satunya adalah kompetensi pedagogik.

Menurut Prof. J. Hoogverld dalam Kurniasih (2017) bahwa pedagogik merupakan ilmu pendidikan anak dimana ilmu ini mempelajari terkait dengan masalah membimbing anak ke arah tujuan tertentu agar mampu secara mandiri untuk menyelesaikan tugas hidupnya. Pentingnya pemahaman guru terhadap kompetensi pedagogik ini untuk melakukan bentuk pengembangan keterampilan sosial agar peserta didik berkebutuhan khusus dapat berkomunikasi, beradaptasi serta mampu menyelesaikan permasalahan di lingkungan sosial.

Beberapa aspek variabel keterampilan sosial yang harus dikuasai pada era globalisasi menurut pemikiran Wagner (2008) dalam Ginanjar (2017) meliputi :

critical thinking an problem solving

Collaboration across network and laing by influence

Agility and adaptability

Initiative and entrepreneurialism

Effective oral and written communication

Accessing and analyzing information

Curiosity and imagination

Faktor pendukung dalam upaya mengembangkan keterampilan ABK (Hernita,2014: 17) meliputi adanya shadow teacher, adanya kerjasama yang diberikan guru (wali kelas) dalam mengembangkan keterampilan sosial ABK, adanya program individu, adanya sarana dan fasilitas $A B K$, penerimaan lingkungan sekolah yang baik terhadap ABK.

\section{METODE}

Pendekatan yang dilakukan dalam penelitian ini adalah melalui pendekatan kualitatif. Fokus penelitian dalam penelitian kualitatif yaitu berada dalam masalah itu sendiri (Sugiyono,2017:55). Latar penelitian ini di SMP Negeri 12 Semarang. Fokus penelitian ini adalah kompetensi pedagogik guru IPS dalam Pengembangan Keterampilan Sosial Anak Berkebutuhan Khusus. Sumber data dalam penelitian ini adalah informan, kenyataan yang diamati atau hasil observasi dan dokumentasi. Informan utama pada penelitian ini adalah guru IPS, dengan informan pendukung yaitu Guru Pendamping Khusus, Wakil Kepala Sekolah dan Peserta didik berkebutuhan khusus.

Teknik pengumpulan data yang digunakan adalah observasi partisipasif, wawancara dan dokumentasi. Kegiatan observasi yang dilakukan oleh peneliti yaitu mengikuti pembelajaran di dalam kelas sebagai pendengar dan mengamati guru mengajar. Guna mendapatkan data yang akurat maka 
peneliti melakukan wawancara mendalam terhadap guru IPS kelas 7 dan 8 serta dikroscek ke peserta didik, wakil kepala sekolah dan guru pendamping khusus. Peneliti juga mengambil data berupa dokumentasi yang meliputi Rencana Perencanaan Pembelajaran (RPP) dan foto kegiatan. Pada penelitian ini menggunakan triangulasi teknik/ metode. Analisis yang digunakan pada penelitian ini menggunakan analisis model interaktif. Analisis interaktif terdiri atas tiga alur yaitu pengumpulan data, reduksi data, penyajian data dan penarikan kesimpulan.

\section{HASIL DAN PEMBAHASAN}

Berdasarkan hasil observasi di SMP Negeri 12 Semarang yang merupakan salah satu sekolah inklusi di Kota Semarang, terdapat dua kelas yang terdapat peserta didik berkebutuhan khusus, yaitu berada pada kelas VII D dan VIII G.

Jumlah anak berkebutuhan khusus di kelas VII D berjumlah empat (4) peserta didik yang memiliki asesmen yang berbeda-beda. Sedangkan di kelas VIII G terdapat tiga (3) anak berkebutuhan khusus yang ditempatkan di kelas tersebut. Berdasarkan hasil pengamatan kegiatan pembelajaran di kelas VII D dengan jumlah 32 siswa, terdapat empat anak berkebutuhan khusus yang bernama Adrianus Therro Nugroho (12 Tahun), Gono Pribadi (13 Tahun), Ira Surya Ningsih (12 Tahun), Naila Ola Nur Fardila (12 tahun) memiliki keterbatasan/ kesulitan penerimaan pembelajaran yang berbeda-beda. Untuk siswa berkebutuhan khusus di Kelas VIII $G$ berjumlah tiga anak yaitu Ceyssar Ramaadzan (13 Tahun), Muhammad Iqbal Saputra (12 Tahun), dan Rasyid Dika Rahmawan (12 Tahun). Guru IPS yang mengajar di kelas VIII adalah Ibu Marhaeni Sri Andayani, S.Pd dan Ibu Ririn Dwi Astuti, S.Pd.,M.Pd mengajar di kelas VII.

\section{PENGUASAAN KARAKTERISTIK ABK}

Berdasarkan hasil penelitian yang dilakukan oleh peneliti terkait dengan penguasaan kompetensi pedagogik guru IPS SMP Negeri 12 Semarang bahwa guru IPS yang mengajar dikelas inklusi yaitu Ibu Ririn dan Ibu Marhaeni telah mengetahui setiap karakter dari peserta didik berkebutuhan khusus. Hal ini sesuai dengan penjelasan yang dikemukakan oleh Ibu Marhaeni sebagai berikut, "Saya juga menghadapinya secara khusus, paling tidak saya berkomunikasi dengan mereka." (Wawancara Ibu Marhaeni, 13 Maret 2020). Dengan adanya komunikasi yang baik antara guru dengan siswa guru dapat lebih memahami dalam mengidentifikasi setiap karakteristik dari peserta didik terutama peserta didik berkebutuhan khusus.

Guru memiliki peran sebagai pendidik sehingga dituntut untuk menguasai ilmu tentang cara mendidik. Selain terampil dalam menyampaikan bahan ajar, seorang guru juga harus mampu untuk mengembangkan pribadi anak, mempertajam hati nurani serta berkewajiban untuk menanamkan karakter dalam diri setiap peserta didik. Guru juga harus mampu untuk memastikan setiap peserta didik terutama peserta didik berkebutuhan khusus mendapatkan kesempatan belajar yang sama dalam pembelajaraan. Berdasarkan hasil pengamatan dalam kelas dan wawancara yang dilakukan, peneliti memperoleh hasil bahwa guru IPS telah dapat memastikan setiap peserta didik tanpa terkecuali peserta didik berkebutuhan khusus untuk siap dalam penerimaan pelajaran. Guru juga telah dapat mengatasi kekurangan dari masing-masing peserta didik berkebutuhan khusus serta membantu peserta didik yang menmpunyai hambatan sehingga dapat melakukan pengaturan kelas untuk dapat memberikan kesempatan belajar yang sama kepada peserta didik berkebutuhan khusus.

Berdasarkan peraturan menteri

Pendidikan Nasional Republik Indonesia Nomor 16 Tahun 2007 tentang Standar Kualifikasi Akademik dan Kompetensi Guru ada 7 (tujuh) aspek dan 45 (empat puluh lima) indikator yang berdasarkan kompetensi pedagogik salah satunya adalah guru mampu menguasai karakteristik peserta didik terkait 
dengan aspek fisik, intelektual, sosial, emosional, moral dan latar belakang untuk membantu dalam proses pembelajaran. Seperti yang dikutip dalam Kurniasih (2017: 45-46) bahwa pemahaman karakteristik peserta didik dapat diketahui dengan kemampuan guru untuk memahami setiap karakteristik dari peserta didik berkebutuhan khusus, memastikan peserta didik ABK mendapatkan perlakuan yang sama untuk berpartisipasi aktif, mengetahui kemampuan belajar dari peserta didik ABK, serta memperhatikan kelemahan ABK agar peserta didik tersebut tidak termarginalkan.

\section{KEGIATAN PEMBELAJARAN YANG MENDIDIK}

nining (2014:2) menyatakan bahwa pemahaman tentang peserta didik secara mendalam dan penyelenggara pembelajaran meliputi pemahaman terhadap psikologi perkembangan anak, kesehatan anak, lingkungan sosial dan kemampuan orangtua murid yang merupakan pemhahaman yang harus dikuasai oleh seorang guru dalam meningkatkan kompetensi pedagogik dalam proses belajar mengajar.

Langkah untuk melaksanakan kegiatan pembelajaran yang mendidik adalah seorang guru mampu melaksanakan penyusunan terhadap Rencana Pelaksanaan Pembelajaran (RPP), dimana berdasarkan Surat Edaran Mendikbud Nomor 14 Tahun 2019 tentang Penyederhanaan Rencana Pelaksanaan Pembelajaran (RPP) komponen inti dalam RPP meliputi tujuan pembelajaran, langkah-langkah (Kegiatan) pembelajaran dan penilaian (assesment). Seperti yang dikatakan Ibu Ririn, . "Ya saya tetep berpedoman di RPP, setelah itu untuk anak-anak berkebutuhan khusus kita turunkan grade nya walaupun materi kita tetap itu ya . jadi kalau ditanya saya pinginnya yang mana ya saya pingin ikut pelatihan biar saya tau harus bagaimana." (Wawancara Ibu Ririn,5 maret 2020).

Pelaksanaan kegiatan pembelajaran Peserta didik diberikan stimulus untuk berfikir kritis terkait dengan aktifitas kegiatan manusia, sehingga Peserta didik dapat memahami materi yang disampaikan dengan mudah serta tujuan pembelajaran sesuai dengan kurikulum dapat tercapai. Berdasarkan hasil pengamatan yang telah dilaksankan oleh peneliti dalam kegiatan pembelajaran di dalam kelas VII D dan VIII G, pembelajaran yang dilakukan guru IPS sudah menarik dan bervariasi, tidak hanya menyangkut hanya pada teori saja namun dikaitkan dengan apa yang terjadi dalam kehidupan sehari-hari. Media pembelajaran yang diguanakan juga bervariasi seperti PPT atau model pembelajaran seperti cross word, hidden word, arisan, atau beberapa permainan lain yang menarik minat peserta didik untuk mendapatkan materi sesuai dengan tujuan pembelajaran.

\section{PENGEMBANGAN POTENSI DAN KETERAMPILAN SOSIAL ABK}

Salah satu bentuk analisis yang dilakukan guru untuk mengidentifikasi pengembangan potensi peserta didik adalah dengan merancang dan melaksanakan aktivitas pembelajaran yang memunculkan daya kreatifitas dan kemampuan berfikir kritis peserta didik. Pemahaman terhadap pengembangan potensi peserta didik yang selanjutnya dapat diketahui dengan mengidentifikasi cara guru melihat kelebihan atau kelemahan peserta didik dan kesulitan belajar masing-masing peserta didik agar dapat mengetahui potensi dari peserta didik.

Pemahaman guru terhadap kelebihan dan kekurangan dari peserta didik terutama peserta didik $\mathrm{ABK}$ memudahkan guru untuk memantau terkait perkembangan keterampilan sosial dari peserta didik. Pengembangan keterampilan sosial yang diteliti adalah terkait dengan pengembangan yang dilakukan oleh guru terkait dengan keterampilan sosial seperti komunikasi yang efektif dari peserta didik berkebutuhan khusus, kemampuan beradaptasi atau bersosial dari peserta didik serta kemampuan peserta didik untuk berfikir kritis dalam pemecahan masalah yang dihadapinya. 
Berdasarkan hasil wawancara dan observasi yang dilakukan peneliti bahwa anak berkebutuhan khusus di SMP Negeri 12 Semarang tidak mengalami kendala yang berarti terkait dengan komunikasi. Pengembangan keterampilan sosial yang berkaitan dengan komunikasi peserta didik berkebutuhan khusus oleh guru mata mata pelajaran IPS sudah dilakukan dengan sangat baik, yaitu dengan cara guru tersebut mengetahui kemampuan komunikasi dari setiap peserta didik berkebutuhan khusus serta selalu mengawasi terhadap perkembangan keterampilan sosial yang terkait dengan komunikasi efektif dari peserta didik ABK dalam pembelajaran di kelas masing-masing.

Pengembangan keterampilan sosial oleh guru terhadap anak ABK yang selanjutnya adalah terkait dengan keterampilan beradaptasi. Beradaptasi berarti mampu menyesuaikan diri dengan lingkungan sekitarnya. Berdasarkan hasil pengamatan peneliti pada kegiatan pembelajaran dalam kelas yang dilaksanakan tanggal 19 Februari 2020 bahwa penerimaan peserta didik berkebutuhan khusus oleh warga SMP Negeri 12 Semarang sangat baik. Dalam pembelajaran di kelas, peserta didik lain membantu kesulitan yang dialami oleh peserta didik. peserta didik lain mempunyai toleransi yang tinggi terhadap keberadaan ABK. Hal tersebut sejalan dengan hasil wawancara yang dilakukan peneliti terhadap Ibu Ririn selaku guru IPS kelas VII. "Kalau menurut saya hanya perlu waktu sebulan untuk teman-temannya (mampu adaptasi), berkali kali kita berikan pengertian. Saya kira ga ada masalah untuk itu" (Wawancara Ibu Ririn, 5 Maret 2020)

Perngembangan keterampilan sosial peserta didik selanjutnya adalah pengembangan keterampilan berfikir kritis atau memecahkan masalah peserta didik berkebutuhan yang dilakukan oleh guru mata pelajaran IPS. Di usia remaja, rasa keingintahuan terkait sesuatu sangat tinggi. Tidak terkecuali dengan anak berkebutuhan khusus. Berbagai masalah yang dihadapi oleh setiap individu dengan individu lainnya tidak sama. Anak berkebutuhan khusus yang memiliki kendala secara fisik maupun psikis mempunyai pemikiran tersendiri terkait dengan permasalahan yang ada di sekitar mereka. Guru memberikan stimulasi dengan memberikan contoh permasalahan sehari-hari sehingga anak berkebutuhan khusus mampu mengasah kemampuan berfikir kritisnya.

\section{FAKTOR PENDUKUNG PENGEMBANGAN KETERAMPILAN SOSIAL ABK}

\section{Pendamping Khusus/ Shadow Teacher}

Keberadaan guru pendamping khusus menjadi salah satu pndukung dalam peengembangan keterampilan sosial yang dilakukan oleh guru. Guru pendamping khusus memiliki beberapa tugas diantaranya adalah melakukan pendampingan terhadap peserta didik berkebutuhan khusus dalam kegiatan pembelajaran, melakukan bentuk monitoring terhadap perkembangan anak berkebutuhan khusus, serta melakukan bentuk kerjasama dengan orangtua/ wali murid ABK. Di SMP Negeri 12 Semarang terdapat satu orang Guru Pendamping Khusus Beliau adalah Bapak Galih Priambada, S.Pd.

Keberadaan Guru Pendamping khusus memberikan kemudahan untuk melakukan bentuk pengkomunikasian terhadap kendala yang ditemui oleh guru maupun orangtua/ wali dari peserta didik berkebutuhan khusus itu sendiri. Guru mata pelajaran seringkali mengalami kesulitan ketika harus dihadapkan dengan anak berkebutuhan khusus dimana mereka belum pernah mengajar sebelumnnya. Dengan adanya komunikasi dengan guru mata pelajaran maupun wali kelas memudahkan setiap guru mengidentifikasi perlakuan peserta didik berkebutuhan khusus secara benar dalam kegiatan pembelajaran.

Keberadaan guru pendamping khusus sangat penting terhadap keberadaan anak berkebutuhan khusus di sekolah inklusif. Guru pendamping khusus mengerti kebutuhan dan hal-hal apa saja yang harus dilakukan untuk menghadapi anak-anak berkebutuhan khusus dengan berbagai asesmen. 


\section{Kerjasama Orangtua Dan Sekolah}

Penyelenggaraan sekolah inklusif mengharuskan sebuah sekolah untuk melakukan bentuk penyesuaian baik dalam segi kurikulum, sarana prasarana maupun sistem pembelajaran yang disesuaikan dengan kebutuhan peserta didik maupun. Bentuk komunikasi serta kerjasama dari pihak sekolah juga menjadi sebuah hal yang sangat penting untuk memantau serta mengevaluasi perkembangan dari anak didik itu sendiri.

Berdasarkan hasil wawancara peneliti terkait dengan kerjasama sekolah orangtua/ wali murid peserta didik berkebutuhan khusus dengan Ibu Kusni (Wakil Kepala Sekolah) bahwa telah dilaksanakan dalam bentuk pertemuan antara orangtua peserta didik dengan pihak sekolah yang diwakili oleh guru pendamping khusus. "Ada (kerjasama), Tapi itu Mas Galih (shadow Teacher) yang menangani. Khusus Shadow teachemya dan mungkin kepala sekolah, karena itu memang rahasia Mbak. Kita guru ya bersama dengan anak-anak biasa kalau pas pagi, tidak ada pertemuan khusus." (Wawancara Ibu Kusni, 10 Februari 2020).

Terbentuknya sebuah kerjasama yang baik antara orangtua/ wali peserta didik berkebutuhan khusus telah terbentuk dengan baik di SMP Negeri 12 Semarang. Kerjasama dilakukan dalam bentuk laporan kegiatan peserta didik yang dilakukan secara onlinemelalui pesan WhatsApp serta bentuk pertemuan secara langsung. Sehingga orangtua dapat melakukan bentuk pemantauan perkembangan peserta didik baik akademik maupun keterampilan yang dapat dikembangkan lagi ketika seorang anak berada di lingkungan keluarganya sendiri

\section{Sarana dan Prasarana}

Penyelenggaraan sekolah inklusif, dalam keberadaannya harus memenuhi kelengkapan sarana dan prasarana yang disesuaikan dengan kebutuhan dari peserta didik berkebutuhan khusus. Peserta didik berkebutuhan khusus di SMP Negeri 12 Semarang memiliki keterbatasan baik itu fisik maupun psikis, oleh karena itu sebagai sekolah yang mempunyai misi untuk mewujudkan sekolah inklusif yang ramah terhadap keberadaan anak berkebutuhan khusus sekolah haruslah menyediakan sarana dan prasarana penunjang pembelajaran sesuai dengan kebutuhan dari masing-masing peserta didik. sarana dan prasarana juga dapat menjadi sebuah jalan untuk menyalurkan bakat atau potensi peserta didik tak terkecuali peserta didik berkebutuhan khusus. Hal tersebut secara tidak langsung akan memberikan fasilitas tehadap perkembangan sosial peserta didik terutama dalam hal keterampilan sosial.

Berdasarkan hasil wawancara peneliti dengan Ibu Kusni selaku Wakil Kepala SMP Negeri 12 Semarang bahwa sekolah telah menyediakan sarana dan prasarana untuk menunjang kegiatan pembelajaran disekolah seperti ketersediaan kursi roda dan jalanan miring untuk memudahkan penggunaan kursi roda tanpa harus diangkat. Selain itu sekolah juga memfasilitasi dengan peralatan penunjang keterampilan seperti Laboratorium komputer, alat masak, alat olahraga dan masih banyak lagi.

\section{FAKTOR}

\section{PENGEMBANGAN}

\section{PENGHAMBAT}

\section{SOSIAL ABK}

\section{Diri Sendiri/ Individu}

Pengembangan keterampilan sosial peserta didik terdapat faktor penghambat dalam pengeembangan keterampilan sosial. Faktor pertama adalah faktor dari diri sendiri. Seseorang memiliki tingkat perkembangan sosial yang berbeda-beda. Seorang anak usia sekolah mulai menunjukkan peningkatan kepedulian terhadap teman sebaya.

Berdasarkan hasil pengamatan yang dilakukan oleh peneliti ketika mengikuti pembelajaran dalam kelas VII maupun VIII yang terdapat peserta didik berkebutuhan khusus, keberadaan peserta didik ABK ini sudah diterima baik oleh teman-temannya. Hal tersebut dapat ditunjukkan ketika melihat respon peserta didik lain yang membantu mereka jika mengalami kesulitan ataupun hambatan ketika 
kegiatan pembelajaan berlangsung. Peserta didik berkebutuhan khusus memiliki beberapa kendala ketika pembelajaran, seperti keterbatasan fisik maupun kesulitan memahami materi dalam pembelajaran. peserta didik juga memiliki tingkat kepercayaan diri yang rendah sehingga masih menutup diri, terutama untuk ABK di kelas VII. Namun peserta didik lain sudah menerima kehadiran mereka dengan baik hal tersebut ditunjukkan dengan sikap peserta didik lain yang dapat menghargai dan menghormati terhadap perbedaan dari mereka.

\section{Pelatihan Pembelajaran Kelas InklusI}

Guru harus memiliki pengetahuan dalam melakukan pembelajaran di kelas inklusi. Hal tersebut sangat penting terutama guru mata pelajaran dimana pada umumnya mengajar di kelas reguler dan secara tidak langsung diharuskan untuk dapat menyesuaikan terhadap pembelajaran yang diperuntukkan terhadap anak yang mempunyai keterbatasan dan memerlukan pelayanan khusus. Monitoring dan evaluasi dari dinas pendidikan terkait dengan program sekolah inklusi ini harus dilakukan secara berkesinambungan. Pelatihan yang dilakukan sejauh ini hanya sekali dan belum dilakukan secara berulang. Dari hasil wawancara dengan guru IPS, mereka pada awalnya mengalami kesulitan namun menjadi semakin terbiasa. Kurangnya pelatihan pembelajaran yang dilakukan oleh dinas pendidikan menjadi hambatan untuk mengoptimalkan pembelajaran yang di dalam kelas karena guru kurang optimal dalam memahami asesmen dan bentuk perilaku yang harus dilakukan. Guru juga mengeluhkan kesulitan dalam penanganan terhadap peserta didik berkebutuhan khusus karena kurangnya pelatihan dari dinas pendidikan.

\section{SIMPULAN}

Penguasaan kompetensi pedagogik guru IPS dalam pengembangan keterampilan peserta didik berkebutuhan khusus di SMP Negeri 12 Semarang sudah baik. Terdapat 2 guru IPS yang mengajar di kelas inklusi. Guru tersebut mengajar di kelas VII dan kelas VIII dimana masing-masing dari mereka telah mengetahui dan mengimplementasikan ilmu pedagogi dalam membimbing anak, melaksanakan tugas sebagai pendidik serta menunjukkan bagaimana perilaku yang semestinya dilakukan dalam menghadapi peserta didik.

Terdapat beberapa aspek terkait dengan faktor pendukung dan penghambat dalam pengembangan keterampilan sosial peserta didik berkebutuhan khusus, faktor pendukung tersebut adalah individu guru pendamping khusus/ Shadow Teacher, kerjasama orangtua dan sekolah dan sarana dan prasarana. Sedangkan faktor penghambat pengembangan keterampilan sosial peserta didik berkebutuhan khusus berasal dari anak berkebutuhan khusus/ diri sendiri,.serta kurangnya pelatihan pembelajaran di kelas inklusi.

\section{DAFTAR PUSTAKA}

Balqis, Putri dkk. 2014. Kompetensi Pedagogik Guru Dalam Meningkatkan Motivasi Belajar Siswa Pada SMPN 3 Ingin Jaya Kabupaten Aceh Besar. Jurnal Administrasi Pendidikan. 1(2) 25-38. Aceh: Pascasarjana Universitas Syiah Kuala

Ginanjar, Asep. 2016. Penguatan Peran IPS dalam Meningkatkan Keterampilan Sosial Peserta Didik. Jurnal HARMONY Pembelajaran IPS dan PKN. Semarang : Prodi Pendidikan IPS dan MGMP IPS PKN Kota Pekalongan.

Hernita, Nining. 2014. Upaya Mengembangkan Keterampilan Sosial Anak Berkebutuhan Khusus di Sekolah (Studi Kasus di SD Citra Alam). Jurnal Departemen Ilmu Kesejahteraan Sosial.Jakarta: FISIP UI.

Kemendikbud. 2016. Gambaran Sekolah Inklusif di Indonesia (Tinjauan Sekolah Menengah Pertama). Jakarta : Pusat data dan Statistik Pendidikan dan Kebudayaan

Kurniasih. 2017. Kupas Tuntas Kompetensi Pedagogik Teori dan Praktik untuk 
Azizah Nur Aini Muslichah, dkk / Harmony 5 (1) (2020)

Peningkatan Kinerja dan Kualitas Guru. Jakarta: Kata Pena

Pemerintah Indonesia. 2003. Undang-Undang Republik Indonesia Tentang Sistem Pendidikan Nasional Nomor 20 Tahun 2003. Jakarta: Sekretariat Negara

Pemerintah Indonesia. 2005. Undang-Undang Republik Indonesia Tentang Guru dan Dosen Nomor 14 Tahun 2005. Jakarta: Sekretariat Negara

Peraturan Menteri Pendidikan Nasional Republik Indonesia Nomor 16 Tahun 2007 Tentang
Standar Kualifikasi Akademik dan Kompetensi Guru. Jakarta. Plh. Kepala Biro Hukum dan Organisasi Kepala Biro Kepegawain

Sugiyono. 2017. Metode Penelitian Kualitatif. Bandung: Alfabeta

Surat Edaran Menteri Pendidikan Nasional Republik Indonesia Nomor 14 Tahun 2019 Tentang Penyederhanaan Format RPP. Jakarta. Plh. Kepala Biro Hukum dan Organisasi Kepala Biro Kepegawaian. 